\title{
HOW EFFORTS TO DEVELOP THE EXPERTS AND MANPOWER PROFESSIONAL IN INDONESIA
}

\author{
Menara Simanjuntak; Haryadi Sarjono \\ Management Department, Faculty of Economic and Communication, BINUS University \\ Jln. K.H. Syahdan No. 9, Palmerah, Jakarta Barat 11480 \\ menara0110@yahoo.com, haryadi_s@binus.edu, haryadisarjono@yahoo.com
}

\begin{abstract}
Development experts and skilled professionals in Indonesia is still needed today. This paper highlights the development efforts of experts and professionals in the Indonesia's executive power, as well as scientific studies which could give input for the government or educational institutions and industry. The approach used in this paper is library study by exploring the relevant references to the topic, and performed descriptive analysis. Institutions, such as universities and secondary vocational schools, are expected to produce skilled professionals with specific competence requirements. It is expected the government to prioritize opportunities to those less educated to follow a course skills, because they are the largest part of today's workforce. The weakness today is still a lot of educational institutions that do not have adequate infrastructure according to the requirements specified. The important conclusion is that the government is expected to give impetus and greater responsibility for higher education institutions, vocational schools and training centers and courses of work skills. In addition to the certification body to work more effectively because many Indonesian workers within and outside the country who do not yet have certification.
\end{abstract}

Keywords: experts and skills professionals, university, vocational schools, training centre

\begin{abstract}
ABSTRAK
Pengembangan keahlian dan keterampilan profesional di Indonesia masih dibutuhkan saat ini. Tulisan ini menyoroti usaha-usaha pembangunan ahli dan profesional di Indonesia kekuasaan eksekutif, dan juga studi ilmiah yang bisa memberi masukan untuk pemerintah atau lembaga-lembaga pendidikan dan industri. Pendekatan yang digunakan dalam makalah ini adalah studi perpustakaan dengan menjelajahi referensi yang relevan dengan topik, dan melakukan analisis deskriptif. Lembaga-lembaga, seperti universitas dan sekolahsekolah kejuruan sekunder, diharapkan untuk menghasilkan tenaga profesional dengan persyaratan tertentu kompetensi. Diharapkan pemerintah untuk memprioritaskan peluang kepada orang-orang yang kurang berpendidikan untuk mengikuti kursus keterampilan, karena mereka adalah bagian terbesar dari tenaga kerja hari ini. Kelemahan saat ini adalah masih banyak institusi pendidikan yang tidak memiliki infrastruktur yang memadai sesuai dengan persyaratan yang ditentukan. Tulisan ini memberikan simpulan penting bahwa pemerintah diharapkan untuk memberikan dorongan dan tanggung jawab lebih besar untuk institusi pendidikan tinggi, sekolah kejuruan dan pusat pelatihan dan kursus keahlian kerja. Selain itu, badan sertifikasi perlu bekerja lebih efektif karena banyak pekerja Indonesia di dalam dan di luar negeri tidak memiliki sertifikasi.
\end{abstract}

Kata kunci: keahlian dan keterampilan profesional, universitas, sekolah kejuruan, pusat pelatihan 


\section{INTRODUCTION}

The growth of the workforce in Indonesia is inseparable from the continued high rate of population growth, while employment depends heavily on the availability of jobs. Agency for Population and Family planning in the website his release in July 2011, the population of Indonesia in 2011 reached 241 million. This reinforces that the natural population increase Indonesia every year for Singapore's population of about 3.5 million people, then within the next 20 years they enter the workforce. They will enter a new employment or replace those who retire or do not work anymore. New jobs created by the creativity of a State Government through the implementation of policies and development strategies in the State. Increased economic growth of a country does not automatically provide new jobs. The situation today shows that most of the new workforce is less educated and less than 5 percent of college-educated, and about 30 percent of high school educated and the rest are equal and junior elementary education. Each year only about 10 percent of the workforce is entering formal employment (Government and Private), approximately 25 percent entered the informal sector and about 30 percent longer a subtle unemployment (disguised employment) that share the cake with nonformal workers that previously existed in the area, and the remaining 35 percent accumulate from year to years of unemployment.

In nominal amount of unemployment continues to increase despite accumulating expressed in percentage according to the BPS down and rightly so because the population continues to grow. Economists said that every percent of economic growth will be absorbing 500,000 new jobs, although there is economic growth that does not always add jobs. According to BPS publication July 14, 2011 Director of the analysis and development of BPS Statistics states that in the last three years figures Unemployment rate fell from 8.14\% in February 2009 to be 6.8\% in February 2011. The decline is in line with the increasing number of women working abroad. This is the problem that arises out of late, that the Government of Indonesia less attention to the legal protection for workers with low education who are working abroad when problems arise that are not desired. Overview of labor in Indonesia as reported of United Nations Conference on Trade and Development (UNCTD, 2007), is still largely in the agricultural sector (2.75), followed by the tourism sector ( 0.74$)$, following new non-manufacturing (0.67) and manufacturing (0.51).

Problem provision of employment any country has always depended on the creativity and innovation policy of the state government's economic development is concerned. In the early decades of the 21st century is still faced with the State of Republic Indonesia high unemployment, in addition to job opportunities ranging from increased infrastructure development, as well as extending the various sectors of the economy, especially agriculture, tourism, and manufacturing is expected to be the solution. Terms of preparation of the workforce should be treated conceptually with the aim of making every work force more professional than the previous decade. So that is at issue in this study is how to prepare a professional workforce in this decade to be ready to enter the workforce in Indonesia and abroad.

\section{DISCUSSION}

The core elements of a profession are possession of a specialized body of knowledge and commitment to service. The Oxford Dictionary defines a profession classic as: "the occupation which one professes to be skilled in and to follow. a) a vocation in the which professed knowledge of some department of learning or science is used in its application to the affairs of others or in the practice of an art founded upon it, $b$ ) in a wider sense any calling or occupation by the which a person habitually earns his living." 
In the field of sport known amateur players and professional players such as football, boxing, tennis, and basketball. Amateur players could probably play a sport something better than a professional player, but his achievements are not paid with money, just a trophy, medal or plaque and other gifts. Unlike the professional players in addition to getting an award of trophies and medals, they also paid for with money in accordance with his performance. The higher the achievement, the higher the fee. A professional world boxing champion for a particular class to defend his pay ranges from USD \$ 5-15 million each to the ring, a professional football player in the European leagues get paid starting from USD \$ 10,000 in league division one, while in the premier league players like Cristiano Ronaldo (Real Madrid), Lionel Messi (Barcelona), Wayne Rooney (Manchester United), and Davis Beckham recorded earnings of up to USD \$. 400,000 per week. Similarly, a senior accountant who works on multinational corporations in the USA get paid Rp. 3.5 billion per year, but after the immediate crisis was down in 2009 to just below Rp. 1 billion, because the company where she/he worked was near death and participates in the bailout.

A profession arises when any trade or occupation transforms itself through "the development of formal qualifications based upon education, apprenticeship, and Examinations, the emergence of regulatory bodies with powers to admit and discipline members, and some degree of monopoly rights (Bullock \& Trombley, 1999, p. 689).” Professional workers differ with those who are not professional. The professional is more stable and have a commitment to work longer in the field of expertise. According to Allen \& Katz (2002) that they are more loyal to the profession rather than status as workers. To master them, then regularly require refreshing or sharpen his knowledge, because they are more committed to the profession than those who start work at 8:00 am to 17:00 pm, five days a week. A motivation of the professionals seems to be a corresponding payment and enjoys their work, while the money and promotion are the priority contrast with job opportunities with a higher level. They prefer to deal with getting solutions to problems. Their superiors to reward them for their work, namely the work itself. A professional accountant rather was sent out to audit a company's financial / industrial rather than assigned the position as section chief in the office, as well as an information systems analyst is more like getting up the task of designing an enterprise information system is being, or auditing a large enterprise system, rather than deal with it other in-office.

The professionals also need the support of values, which they want others to share thinking about what they're doing is important. This may be true for all workers, but for professional workers tend to be more focused on their work as a center of interest of their lives. While those with nonprofessional workers do not forget the money, because they have other interests outside of work that can compensate for the social needs that they do not find in their work. Professional skills refer to the necessary skills for graduates to succeed in professional practice. They include the "generic," or "transferable" skills listed in the resume of many discussions, and also include the attributes of selfmotivation; self-confidence; self-management: self-promotion; as well as the ability to understand ethical conduct ; meet deadlines; be punctual; get on well with others in the organization and clients; and shows initiative. In western nations, Such as the United States, the term of commonly describes highly educated professionals, Mostly salaried workers, who enjoy considerable work autonomy, a comfortable salary, and are commonly engaged in creative and intellectually challenging work experts and professional workers do not appear by itself, but must go through the process of education, training and experience of the rather long.

People Republic of China with population of approximately 1.3 billion with a very strict control, i.e. one family one child, as well as the first college entrance selection began in a family environment by recognizing the academic potential of the child since elementary school and secondary school. Then pass the junior has no recommendation from the school, that child is placed into a specific vocational high school and this is the second selection. They recommended going to college was to go through the selection, because the chairs in universities in the PRC are also limited. There is always that force their children to go to college when the child's abilities and talents should be through other channels that level study program. This situation is increasingly organized for the last 30 years 
and the PRC began to reap the rewards are amazing, not just from the spread of the workforce into different sectors increasingly targeted, but its economic growth over the last ten years held the world record around the average growth of about 9 percent thanks to the understanding greatly in the importance of prioritizing infrastructure development. Currently China has the world's highest foreign exchange reserves equivalent to USD \$ 3 trillion in debt securities as well as holding various countries the equivalent of USD \$ 2.5 trillion. As of this writing there has been no international publication that states that the PRC is the country's most creative and innovative and the most advanced today. On the other hand that the equitable distribution to rural development outcomes have not been fully achieved, the poverty rate is still quite large. Indonesia with an average economic growth on average by 6 percent in the past decade has not been fully able to absorb the labor force. On the other hand has not seen the government's efforts to significantly reduce the number of unemployment and poverty.

In the short term the most easily provide employment is in infrastructure development because it can absorb the labor including non-professionals, where it has been practiced by the USA in dealing with the crisis of 2009. But the problem is that infrastructure development requires considerable cost and this policy should be parallel with the policy provision in the medium-term employment in other sectors such as agriculture, mining, tourism and manufacturing as well as services that also require investment. Along with the development policies in various fields is then a country's national education policy should be integrated with other sectors such as construction that has been practiced not only in Japan, South Korea is also in China. Educational policies in these three countries are to meet future labor market. Specifically designed program also advocates colleges with vocational schools and courses in the college itself to print the skilled labor as well as executive managers and workforce professionals.

\section{Professional Workforce Needs in Indonesia}

Absorption of experts and skilled manpower in various fields of industry in general will be even greater if there is growth in the industry concerned. For the situation in Indonesia will be the same chances in the agricultural sector (agro-industry), tourism sector, manufacturing sector and nonmanufacturing sector in the short and medium term, especially in the long run. If the manufacturing sector will be more and more dependence on both foreign investment and technology equipment. While the agriculture sector be fully satisfied in the country including land availability, agricultural equipment and fertilizers. The growth of the tourism industry also relies heavily on the availability of

supporting infrastructure that requires both public and private investment. While the nonmanufacturing sector depends heavily on economic growth and industry in general.

\section{Skilled Manpower in the Agricultural Sector}

State of Indonesia is an agrarian country that about 60 percent of the population livelihood as farmers, ranchers and fishermen. Employment in this sector is the largest in Indonesia. The majority of farmers grow rice, then the business such as rubber plantations, coconut and oil palm, cocoa, coffee, tea and various kinds of other economically valuable plants, and they began to cultivate horticultural produce various kinds of fruits, tubers and vegetables. Also performed as industrial forest management, teak wood, sandal-wood, pine and other trees agates to the needs of industrial raw material properties, pulp and so on. In 1986, Indonesia rice surplus, and then the next 10 years back import rice, partly due to increasing demand for rice as staple diet of the population changes of other foodstuffs such as sago, cassava, tubers and corn turned into rice, and as a result the increasing population and decreasing agricultural land is being lost in residential and industrial locations. Efforts in the 1990s in the form of the declaration of a million hectare of agricultural land clearance are not followed up intensively, including use of idle land for planting crops horticulture. 
Until this very day announced the expansion of agricultural land and agricultural intensification. To achieve these objectives, in fact necessary expertise and skilled labor are quite large in the agricultural sector including livestock and fisheries work in the industry / company. Agricultural experts are needed from experts who master the technological infrastructure of irrigation, land preparation and processing, breeding and planting, fertilizing, pest control, post harvest product processing and food processing industry. Needs skilled experts and implementers are also needed in developing the plantation and horticulture crops, livestock, fishery and processing industry, including managing agro-tourism industry. Experts generated institute/faculty/college/polytechnic and the Academy, while the executive power is generally produced by skilled vocational high schools.

\section{Experts and Skilled Manpower in the Manufacturing Industry}

Manufacturing industry is characterized by the process of converting raw materials into semifinished materials and finished goods that are supported by equipment and machinery and auxiliary materials, as well as controlled and operated by skilled and professional workers. Indeed there are still manufacturing industries that do not use high-tech industries such as cigarettes and only require trained manpower to do it by using simple tools. There are also industries that do not require prospective workers vocational graduates, but it's entirely necessary skills through training conducted by the industry concerned.

For example workforce trained to assemble electronic equipment only minimal secondary graduates. But skilled labor who served as controller in the industry required a minimum of vocational graduates majoring in electronic engineering, and if there are changes in technology, then this is what the first supervisors sent for training in the country of origin, among other industries such as Japan and South Korea. A similar thing happened in the automotive industry and the like. In many manufacturing industries in the field of engineering expertise required for the development of processing technology and the product itself, as well as personnel supervisor and manager. At a managerial level as well as controlling the operation required skilled operation based undergraduate education, while the power entrusted to skilled operators who have previously undergone adequate orientation and training.

In case of relocation of industries within and outside the country, then the supervisors and lower managers and engineering experts who are skilled professionals are bound contracts with more salary to relocate. These skilled professionals have considerable bargaining power, even then they can decide themselves to move to any company in the same industry, inside and outside the country. While the ordinary skilled labor to do layoffs in return, then they are looking for a job to the same industry that developed the industry as one of the competitors have moved. If they don't choose to work at other companies including comfortable enough to open his own repair shop serving the motor cycle maintenance and services, TV, AC, Car, and so on. Companies receiving skilled labor group that moved the company's former greatly benefited, because it does not require substantial training costs. Only a quite simply the orientation of the adjustment during the week they are able to work with a normal capacity.

\section{Experts and Skilled at Non-Manufacturing}

Wide range of expertise and skill required in executing non-manufacturing sectors, such as requiring health sub-sector experts such as doctors educated scholars with different specialties, pharmacists, nutritionists, psychology, graduate nursing, and public health scholars. While the other paramedic personnel who support operations such as midwives and nurses. Similarly in the financial sector require sub-educated economics graduate financial experts, business management and accounting. On legal institutions and legal aid agencies require criminal and civil law expert and international law and constitutional law. In the manufacturing sector is also included sub-sectors of 
public service in various fields such as police, military, government, fire, sanitation, public works, disaster management and so on which require experts from various disciplines as well as skilled as the executor. In the non-manufacturing sub-sector this includes education from kindergarten to university full of experts as well as their need for skilled implementers. Many companies are hiring contractors and skilled experts, including road and bridge construction company, construction of infrastructure such as airports and harbors, buildings and other property that requires not only experts like undergraduate civil engineering, architecture and electrical, but also requires the skilled workers doing construction work, installation of water and electricity, gas, telephone and so on.

\section{Experts and Skilled Manpower in the Tourism Industry}

Tourism sector requires expertise and skilled enough quite a lot of variation and their work in various fields such as transportation, hospitality, restaurant, including arts and culture. on land transportation, sea / lake / river, and air transport requires experts and skilled. Power pilot of an aircraft, ship and train drivers , captain is equivalent to an undergraduate education, as well as the engineers, electrical needs in this area, including areas of transportation management graduate who manages the administration, information, financial and marketing skilled implementers .Manpower also indispensable in considerable amounts. The helmsman other land transportation such as buses and cars require skilled enough as a driver (interpreter men and women) who have an international license. The tourists are very often asked the driver: "are you have a driving license?”

We also know very much needed as well as scholars in the field of hospitality experts and skilled support as scholars in the field of financial management, accounting, marketing, communications, information, nutrition, environmental sanitation techniques and so on. Especially skilled personnel needed hospitality and restaurant more streamlined as a bar tender, cook and interpreter-restaurant, makeup, massage at the spa interpreter, including the event organizer for the celebration activities held in the hotel and restaurant. Similarly, the building arts, theater and other arts performances where much-needed skilled manpower in the field of arts, including music, dance and sound art. Hospitals are also listed in the requirements demanded by the tourists, package delivery companies, international telephone network, the post office and the police department needs to hire skilled professionals. Visits to museums, traditional markets to the location of a tourist destination with the merchants who were there trying my best able to conduct transactions in English is very simple and it's also part of their skills. Do not forget the tour guide uses the international language of skilled and good at communicating the ethical is a profession long known in the tourism industry. Establish professional experts.

Professional experts in question is at least college graduates (this is also open to question), which also must pass competency exams in their field of theory and practice to obtain a professional certificate. Similarly, universities are considered able to produce graduates that are in line with expectations that meet the accreditation criteria of adequate condition: (1) colleges that have the infrastructure of buildings and classrooms, faculty room and secretariat room, library and laboratory practices are adequate and sufficient facilities campus environment as well, and has accreditation; (2) the availability of a number of lecturers who have the competence and suitability background of his knowledge as evidenced by the certificate owned by the masters and doctoral level to teach certain subjects in the majors/courses of study and have been certified. Along with the lecturer concerned it ranks given academic credit based on figures collected in the field of education and teaching, research and community service/practice of scientific work; (3) availability of infrastructure library and the number of books up to date as the source and reading materials for students and lecturers and the library website which has links to various sources of books, journals, articles and research reports are published. Also the availability of computers and other audiovisual; (4) the availability of laboratory infrastructure practice with instructor adequate power to produce students who are adept at working on and completing a task or solve a problem. Almost all the departments/study programs require a lab, so 
it is very surprising and very unlikely that someone at the college until graduation degree never experienced in laboratory practice, both the exact sciences and social sciences. Medical school has a relationship with the hospital where medical students practice with guidance.

Geology Department also has an area of natural laboratories in this country, and management majors should also have the various collections of cases to be addressed in the laboratory to simulate management strategies such as marketing, business strategy plans and so on. Again not enough just to follow the example problems during the theory lectures but also takes practice and simulation, which are: (1) establish adequate conditions and minimum value limit (test results) for prospective students who may be admitted to majors/courses of study, thus minimizing the dropout rate, or the knowledge gained no benefit to the student; (2) have a curriculum with materials that constantly lectures on update, as well as reducing the courses become redundant and bullies principal subjects; (3) taking into account the implementation of the comparative aspects of the theory and practice as reflected in the determination of the number of semester credit units are adequate. For example a course with the Information Systems System Design course has a weight of at least 4 credits 4 credits theory and practice and executed as many as 15 meetings in one semester. Similarly, majoring in Accounting Introduction to Accounting at least has a weight of 4 credits 4 credits theory and practice and executed as many as 15 meetings in one semester; (4) the intensity of communication / interaction between the lecturer / instructor with a student with a balanced ratio, and today supported by information and communication technologies, including virtual communication, outside the meeting in the classroom and lab; (5) determination of minimum graduation requirements for higher education students, not only theoretical aspects are also practical, with additional research on the ladder of Strata One, Two and Three; and (6) colleges with agency/consortium to test competency for experts and professionals in doing his job, and who passed immediately given a certificate. Today many countries that require labor from abroad are generally focused on the requirement of certification of skills and expertise of candidates.

Thus, if the things above have been met by higher education institutions is concerned, then the expected outcome is a college graduate ready to enter the workforce and are expected to do work that is obtained is consistent with the educational background. Because if not, then the question will never be a professional expert. Orrell (2001) stated that the work experience, job placement and other forms of work integrated learning at the university can help students develop skills in a professional context and make a smooth transition into the world of work.

Indeed, for certain fields that can not be negotiable, because not only avoid the malpractice because of decisions and actions taken can not be justified scientifically and do not heed the code of ethics of each particular profession. In certain areas of the assembly code of ethics required of certain professions such as field medicine, even a special tribunal for the military, shipping and so that adjudicate violations of the code of ethics in the field of profession. Competence in question is if someone can do a job properly and know some ways to do that. The need for professional skills in the workplace face a number of challenges, particularly how to learn and function in unfamiliar situations and unexpected. Multi-skilled, multi-national project teams, require collaboration, cooperation, flexibility and intercultural awareness, level of high-demand professional and interpersonal skills (Harvey, Moon \& Geall, 1997), who subsequently put forward as following;

Workplace challenges

Teamwork

Changing nature of work
Understanding that the world of work is unpredictable, and requires a wide range of skills for an individual to function effectively.

Group and interpersonal skills are essential when dealing with the collaboration required in multi-skilled, culturally diverse team situations.

Today's workplace requires employees to be multi-skilled; 
Job (in)security

Broader expertise

Transferability of skills

Interactive attributes

Personal attributes

Self skills perform their own administrative tasks; and be aware of modern technological changes associated with their profession.

Employees no longer expect to stay in one job for an extended time. Careers can be built across a range of diverse employment positions.

The workplace involves the demonstration and application of professional skills, which go beyond the normal university requirements for written assessment and exams.

The more environments in which students exercise their professional skills, the more able they are to transfer learning from one learning context to another.

Communication.

Teamwork.

Interpersonal skills.

Intellect.

Disciplinary knowledge.

Willingness and ability to continue learning.

Ability to find things out.

Willingness to take risks and show initiative.

Flexibility and adaptability.

Ability to pre-empt and ultimately lead change.

Self-motivation.

Self-confidence.

Self-management.

Self-promotion.

The vision and mission of the 21st century higher education UNESCO (1998) put forward a vision and mission of higher education that the 21st century cored contents of the report of The International Commission on Education for the Twenty-first Century (Learning: the Treasure Within), chaired by Jacques Delors (UNESCO, 1998), with the main content among others.

Hope the future role of higher education: (a) The range from the local community to the world community; (b) Changes in social cohesion to democratic participation, among them a reality: (i) education and the crisis of social cohesion, (ii) education vs. exclusion, (iii) education and employment pressure on society, and (ii) in the form of democratic participation and civic education practice of citizenship; and (c) From economic growth to human development.

The principle of development of education, such as: (a) The four pillars of education: (i) learning to know, (ii) learning to do (the change of skills into competent, dematerialization of the work and the rise of service sectors, as well as working in the informal economy), (iii) learning to live together, learning to live with others (discovering others and working toward common objectives), and (iv) learning to be; and (b) Lifelong learning (learning throughout life) as being: (i) the imperative for democracy, (ii) multidimensional education, (iii) the emergence of new times, fresh fields, (iii) education at the heart of society, and (iii) need for synergy in education.

Direction of development of education, especially higher education: (a) Unitary basic education up to college: (i) basic education as a "passport" for the Bohemian, (ii) secondary education (secondary education) as a crossroads to determine life, and (iii) higher education and lifelong education; (b) The college became a place of learning and knowledge resources; (c) The role of higher education to respond to changing labor market; (d) Higher education as a center of culture and learning open to all; and (e) Education for a vehicle of international cooperation 
To build professionalism at a workplace, as Frost (2003) added; the way people Communicate with each other's Very Important plays a role. There needs to be a clear-cut divide the between our personal life and professional life. A workplace is a highly competitive place, and certain employees have the tendency of getting carried away. Work-integrated learning refers to the numerous forms of workplace Such as practicum, field placement, work placement, industry projects, sandwich courses, etc. Howard Partners (2006) stated that the education and training were the resource persons Identified by businesses as a major area of concern - not only in vocational education and training but also in professional and management education (in Gilbert, 1998). Courses and programs in these areas needed to be practice-based, relevant and appropriate for business innovation needs - rather than suiting particular academic interests and pursuits.

As we enter the 21st Century, the concept of professionalism seems a not only to have survived but also to be once more endorsed, albeit in renewed form. Should this renewal build on the Morality and altruism of the original concept, and these qualities Should Be transferred to the new processes through which the profession is held accountable to society. The college graduates must also be more aware of the importance of early well-developed professional skills for career advancement and development early next period. So to become a qualified professional person at least meet the following criteria: (1) college graduates who have knowledge of theory and practice are balanced, making it easier to make adjustments in entering employment; (2) have practical experience or working in the field in accordance with its competence. Ideally the graduates of these colleges have used to work, then increase the level of education/higher strata (undergraduate even graduate); (3) experience working in various project teams, and working with different teams to gain knowledge and experience of an increasingly varied. Working in teams is an essential characteristic in the era of globalization. It would be nice if someone worked for a team with people of multi-nationals to understand different cultures. Because the expert is not enough to just one or two of experience and involvement in the project. Today the workforce to be an expert when experiencing a growing number of job/different projects together in spite of their knowledge base, but the problems that arise in each project will be different; (4) following adequate training range is marked with a certificate. Workshops, seminars, discussion groups and is actively involved in sharing knowledge and experience make a person stay current in their fields. Because science and technology in particular the situation is constantly changing, and there is a field that is so rapidly changing, so the knowledge and skills a person can be quickly outdated; (5) following a competency exam in stages on the field. Is the wrong opinion if the examination was associated only with the certification of competence. Competency exam is usually done by an accreditation body to provide feedback to someone about the various aspects of knowledge and skill in the art that can be practiced properly in accordance with certain standards, so that a person is expected to be motivated to improve their competence; (6) having experience in both individual and team research. For a particular line of work it is absolutely necessary. Research in a broad sense, can be a scientific study, scientific articles, field or laboratory observations presented on a limited basis among peers and widely through scientific publications such as bulletins, scientific journals, scientific magazines and so on. This effort to constantly have a knowledgeable and able to solve problems in creative and innovative; and (7) achieving functional and structural hierarchy in accordance with the profession. Humans do have a life cycle and along with it efforts to improve one's career in the cycle is initiated from the lowest hierarchy, then developed into secondary level and to high achievement as a stage of maturity and in the end all just a distant memory (decline) when entering the age retirement.

These seven criteria mentioned above is very ideal as applied to teaching staff (lecturers) in higher education through the lanes and the rules of the correct rule. Although sometimes certain individuals to obtain a degree without following these rules or the outside lane, but still there are moral standards that need to be accounted for. For example one easily obtain a college degree and even the title of Professor (Professor) without following the rules or the criteria above. Likewise, the professional manager is not enough to rely on only personal experience but is very important to maintain a network with sources of knowledge and new skills, among others, by always having a 
relationship with the alma mater, working to increase knowledge through seminars, reading journals and scholarly articles, involved with the discussion forums in their field.

Many college graduates do not have the skills, because it is crammed with more theoretical than practical. In many developed and developing countries between universities with industry has been the link and match. Ease in Indonesia for certain faculties such as Faculty of Medicine Hospital practice even be a requirement for the existence of schools of medicine, such as the Faculty of medicine with Dr.Cipto Mangunkusumo Hospital, FK-UKI with UKI Hospital and Hospital of PGI, FK-Atmajaya Hospital Atmajaya all in Jakarta, while in regions with Regional Hospital and so on. Students were free to follow the Law Faculty of civil and criminal court cases in the District Court, the Constitutional Court in constitutional cases, and so on. Government agencies and state enterprises in the past ten years has been openly accepted the presence of students according to procedures established institution. There are still many students of the Faculty and specific majors is difficult to enter the industry to conduct field observations, including conducting research for his thesis, including all the majors on the economics faculty.

More than 3000 experts and skilled manpower that comes out of IPTN Bandung working in Malaysia, Singapore, on Boeing and Airbus get paid 3 to 5 times higher than before the termination of IPTN, because they already have the competence and certification in the field of expertise and skills. In July of 2011 PT Garuda Indonesia Tbk., Facing the threat of strike pilots because they are paid nearly half the salary of foreign pilots working in the airline.

These seven criteria mentioned above is very ideal as applied to teaching staff (lecturers) in higher education through the lanes and the rules of the correct rule. Although sometimes certain individuals to obtain a degree without following these rules or the outside lane, but still there are moral standards that need to be accounted for. For example one easily obtain a college degree and even the title of Professor without following the rules or the criteria above. Likewise, the professional manager is not enough to rely on only personal experience but is very important to maintain a network with sources of knowledge and new skills, among others, by always having a relationship with the alma mater, working to increase knowledge through seminars, reading journals and scholarly articles, involved with the discussion forums in their field.

Many college graduates do not have the skills, because it is crammed with more theoretical than practical. In many developed and developing countries between universities with industry has been the link and match. Ease in Indonesia for certain faculties such as Faculty of Medicine Hospital practice even be a requirement for the existence of schools of medicine, such as the FK-UI Medicine (Faculty of Indonesia University) with Cipto Mangunkusumo Hospital, FK-UKI UKI Hospital and Hospital of PGI, FK-Atmajaya Hospital Atmajaya all in Jakarta, while in regions with Regional Hospital and so on. Students were free to follow the Law Faculty of civil and criminal court cases in the District Court, the Constitutional Court in constitutional cases, and so on. Government agencies and state enterprises in the past ten years has been openly accepted the presence of students according to procedures established institution. There are still many students of the Faculty and specific majors are difficult to enter the industry to conduct field observations, including conducting research for his thesis, including all the majors on the economics faculty.

More than 3000 experts and skilled manpower that comes out of IPTN Bandung working in Malaysia, Singapore, on Boeing and Airbus get paid 3 to 5 times higher than before the termination of IPTN, because they already have the competence and certification in the field of expertise and skills. In July of 2011 PT Garuda Indonesia Tbk., Facing the threat of strike pilots because they are paid nearly half the salary of foreign pilots working in the airline. This picture shows the state just bitter and sweet of the differences that have the competence and certification rather than a diploma today. 


\section{The Executive Power is Skilled Professionals}

As executor of skilled performs a specific job in a particular field is the largest portion of labor needed in various sectors. Skilled personnel are adequately generated or equivalent graduate Vocational School (Sekolah Menengah Kejuruan/SMK) or Madrasah Aliah Vocational /MAK), not high school graduates are on track toward college. Equivalent vocational school graduates directly entering the workforce, and is not closed after a job or opportunities while working to improve education at the undergraduate level. The general requirements are worth having a skilled labor and ready to enter the world of work is to be a student at your school: (1) have the infrastructure SMK/MAK adequate as the study's theory, supported by the visualization of learning materials; (2) have an adequate library with various visuals learning materials; (3) having a practice lab to lay out adequate to the adequacy of equipment and materials/ingredients needed in practice; (4) availability and adequacy of teaching staff (teachers) who is also an instructor who has the competence as a teacher/instructor in accordance majors, with a ratio of teachers and students are adequate; (5) curriculum learning/courses/majors that there is a need now and in the future in agriculture, tourism, manufacturing industry and no-manufacturing; (6) SMK/MAK has a comparison of time to learn the theory and practice are adequate, there just are not spurious; (7) the process of teaching and learning theory and practice of work in a team or individually, for work as a team (not groups) are the demands of today; (8) education providers have a standard evaluation of a clear and consistent, accompanied by a recommendation from the school; and (9) vocational school accredited by the institution/consortium formed Ministry of National Education, and graduates can take exams to obtain certificates of competence skilled in the art.

Then the characteristics of skilled labor are expected to be generated by a CMS today are: (1) graduates SMK/MAK; (2) ready to enter the workforce according to their competence; (3) have advanced level skills in doing the work according to the department. Preferably have some advanced skills and implement them and also pass the competency exam and get certified; (4) able to demonstrate working individually and working as a team; and (5) have the willingness to deepen knowledge of theory and practice in accordance with department/field of work.

As we know, that as far as any skills and vocational skills of graduates, when entering the industrial world at least follows the selection, orientation, training, coaching and performance evaluation. Next will be followed by refresher training and further career development through the placement/assignment, training and so on. Company and Industry is responsible for organizing further training, of the company/industry concerned as a user of skilled labor is continually honed into a professional force. Besides SMK/MAK, also known as the courses are skills specific areas held by the institutions/government and private institutions. The government also organizes training centers for those who are less educated (did not complete primary school, primary school, never graduated from junior high school and junior high school graduation) with a limited field training program. Also the private sector is very much organized courses are more intensive and skills can be implemented immediately.

BLK Government should make a priority, because a person with low education if you already have certain skills has potential as highly skilled labor even in its development into a professional. As one feature of the professional to know all parties, that ultimately the industry recipients prioritize their prospective workers who have passed the certification as proof of competency exams. If you rely solely on proof of a diploma course is considered only as a general requirement, but if you already have the certification will gain more value and rewards, including the international labor market. Those with higher valued certifications such as the case of Indonesian nurses who worked at one government hospital in the country Kuwait earned only equivalent to Rp 12 million rupiah per month, but after showing proof of original certification and submit a copy of it on the moon The following are the initial salary equivalent to Rp.38 million per month plus other rights, including apartments. 
Similarly, the driver of a Mercedes Benz limousine from Indonesia who work in Dubai have a driving license that is recognized internationally, then his salary jumps to 2-fold. Opportunities were open very wide, so it is no longer stuck to export less skilled labor and eventually became the butt of the employer and the law in other countries.

\section{Orientation and Training Environment of the Company/Institution}

In general, after it passed the selection that the person who first entered the working world have experienced a period of adjustment with the environment industry/institution where he was hired., Namely orientation and continued with the training. Orientation period is very short only a few days, just recognize the work environment. The new employee is guided by a manager or senior staff in the group invited to see the workers who are working with a brief explanation, observing a variety of work equipment, machinery, raw materials, finished goods, rest areas, canteen, secretariat room, boardroom as he is introduced to some managers, health clinics, fire fighting equipment, emergency stairs, parking lots, and is usually given work clothes uniform, photographs for identification, job safety procedures, fill out employment forms, health insurance and social forms of labor, tax forms for the taxpayer, pension plan and so on. At the next session is a training program that is general in accordance with the relevant areas of industrial activity. In general basic training takes no more 40 hours or a week. Materials provided regarding the purpose, vision, mission, policies of corporate strategy / institutions, the main activities being carried out by the company, organizational structure, company regulations, laws and regulations regarding employment, taxation, health and safety, environment safety work, organizational culture, the values of the organization, even the history of the company/institution/agency.

After the training, they are placed on a particular unit as an internship program under the guidance of the worker/senior staff as a personnel assistant. In larger companies, after an internship program in a month passed, then the following month prospective employees are required to follow specific technical training in accordance with the placement of new employees, the duration depending on the requirements can be less or more than 40 hours. At large companies such as PT Bogasari Tbk, Bank Mandiri, Pertamina, conducted basic training for the field of technical work. For example those who will be placed will be trained in financial management systems and accounting and financial practices adopted by the company complete with theory and practice and process with computers. Usually the training is done at each pre-test and post-test to evaluate candidates knowledge of new employees before training and after training. After being awarded the assignment in accordance with the position and description of duties and remain under the guidance of a senior manager or directly below the coaching supervisor.

On the development of competence and professionalism of employees is concerned, regular employees are required to follow advanced training. Similarly, those who had occupied the lower level manager positions, junior and senior ranks of top management, has designed a program suitable training, including workshops, seminars, study visits and so on. Coaching career employee in question did not stop there, chances are someone is having rotation, promotion, assignment to a branch, or from the Branch to the Centre, even working at the company branches in other countries, depending on the performance evaluation of employee performance is concerned. Further development of knowledge the company offers to its staff managers or prospective managers to follow a program of continuing education, such as graduate and undergraduate. While the advanced training and professional development and career employees is the decision of the Human Resources Manager with the Division Manager. Training for employees can also be held by an institution or in collaboration with the University. Between groups of similar companies in an industry in developed countries agreed to specific skills training, seminars, workshops, can be held by one company that is considered more complete infrastructure. For example airlines in Indonesia sent its pilots and technicians to attend refresher training courses at training centre of PT. Garuda Indonesia airlines. 


\section{Training Center}

Government cq Ministry of Labor, Department of Labor in the Province and Regency/Municipality held a training hall (Balai Latihan Kerja) for a particular field of work in accordance with the needs in the areas concerned. BLK infrastructure provided by government through the budget financing of national and regional development. BLK effectiveness is highly dependent on the completeness of the infrastructure which consists of locations and buildings BLK, books, manuals for the theory and practice, equipment and raw materials for the practice, instructors / faculty, as well as the cost of providing adequate. The time required (months) depending on the programs designed for specific skills to graduate with a certificate. The number, training programs BLK existence and today is still very limited, so the infrastructure is still less than adequate. BLK Indeed this is needed today to encourage those with low education and lack skills to unemployed status would be helped to enter formal employment and non-formal education. The advantage of BLK that students are exempted from training fees, and there Occasionally BLK graduates is given packets of work equipment, working capital even spurious accordance with entrepreneurship skills to direct. It must be realized if a person already has certain skills will be motivated to choose a profession according to these skills.

\section{Skills Course}

Indeed many found the course skills areas/certain packages that are more effective and qualified are generally organized by private institutions. Various areas of skill consists of packages such as cooking, baking, sewing, driving a car, auto mechanics and motors, air conditioning service, service of electronic equipment, music courses, beauty, and lathe welding courses, computer operators, accounting, tax, and so on. Participants must pay the cost of the package followed a course, which is likely because the participants pay more earnestly and emerging commitment to follow it. The graduate course is usually more implemented because not much pestered by other subjects such as the vocational school and even university. Outcomes of this course gain employment agencies usually as an ingredient for prospective course participants to choose the institution of the course to acquire skills. For those institutions that are experienced enough skill will always organize courses to update course materials in accordance with developments in technology and knowledge today, so that graduates are more easily get a job. There are some known public institutions such as language courses include English, Chinese, Japanese and Korean languages in Jakarta and several cities in Indonesia with the number of students is quite a lot, so the selection is more stringent because of seating and space is limited.

\section{CONCLUSION}

The growth of the workforce in Indonesia is still high and unemployment is still high. On the other hand the momentum to push the nation's new and more professional workforce is still heavily dependent on government development programs particularly in building infrastructure and providing encouragement and a greater responsibility to institutions of higher education, vocational schools, and job training centers and courses skills.

Government as regulator in the field of education, labor and industry are expected to make policy "link and match" the more clearly to be guided by all parties in order to form an expert and skilled professional future and the future is now in the era of globalization. Universities and vocational schools is still much pestered courses are redundant and interfere with the course subject. Main courses should be given more lenient credit semester on the theory and practice in basic laboratory skills and to instill deeper skills for students. 
The accreditation of institutions/institutions of higher education providers and vocational high schools need to be followed by tougher regulations with specific sanctions, such as the implementation of the competency exam by administering certification expertise and presence as the hallmark of professionalism that has experts and skilled manpower. Please note that the international industrial world only recognizes certification as recognition of competence and an essential requirement for prospective workers who are recruited not just have a graduation diploma college or vocational schools.

Rewards or remuneration and other entitlements received by those who considered competent and has a much greater certification than those who only have a diploma. It is very important to the attention of government and a consortium of institutions to be more diligent conduct competency exams for Indonesian workers, especially those who are willing or are working abroad. Since any problems are discussed and studied is for the welfare of labor itself, and once again with no shame and we must firmly declare without "euphemism" that the value of labor in the world is always measured by the amount of money received as wages/salary.

Indonesia with a population the fourth largest in the world must continue to assess and make a clearer policy in tackling employment. In the present circumstances it is possible to prepare skilled workers from their less educated workers that in fact the biggest proportion of the workforce to have the opportunity to take skills and skinny package of job training skills in the hall.

Being creative and innovative nation that always starts with efforts to increase knowledge and skills of more professional people in various fields as the experience of the countries Japan, South Korea and China. So the government is expected to more intensive review the national education system according to developments in the present and future, and actively disseminates information about national education policies related to the process of becoming skilled professional or executive personnel skilled professionals to the public.

\section{REFFERENCES}

Allen, T.T., \& Katz, R. (2002). Managing technical professionals and organizations improving and sustaining the performance of organization, proyek teams, and individual contributors. Sloan Management Review, summer, pp. 54-55.

Bullock, A., \& Trombley, S. (1999). The new Fontana dictionary of modern thought. London: HarperCollins, p.689.

Central Buerau Statistik of Republic Indonesia (BPS). (2011). Unemployment. Publication on July, 14, 2011.

Clarendon Press. (1989). Oxford English Dictionary (2nd ed.). Oxford.

Frost, P. J. (2003). Toxic emotions at work. Harvard Business School Publishing.

Gilbert, D. (1998). The American class structure: In an age of growing inequality. Belmont, CA,Wadsworth Press.

Harvey, L., Moon, S., \& Geall, V. (1997). Graduates' work: Organizational change and students' attributes. Unpublished. 
Orrell, J. (2001). Work-integrated learning in universities: Cottage industry or transformational partnerships? Paper presented at the GIHE/IPON Symposium on Work-Integrated Learning, Griffith University, Australia.

United Nations Conference on Trade and Development (UNCTD). (2007). Chapter III: The impact of FDI in tourism dimension: Creating and capturing value. United Nations, New York and Geneva.

UNESCO. (1998). Higher education in the Twenty-first Century: Vision and action. World Conference on Higher Education. Paris, 5-9 October 1998. 